\title{
ABNORMALITAS MORFOLOGIS BENIH IKAN LELE AFRIKA (Clarias gariepinus) STRAIN MUTIARA
}

\author{
Bambang Iswanto dan Rommy Suprapto \\ Balai Penelitian Pemuliaan Ikan \\ Jl. Raya 2 Pantura Sukamandi, Patokbeusi, Subang 41263, Jawa Barat \\ E-mail: bambang.is031@kkp.go.id
}

\begin{abstract}
ABSTRAK
Ikan lele Mutiara merupakan strain baru ikan lele Afrika (Clarias gariepinus) hasil pemuliaan yang memiliki keunggulankeunggulan karakteristik budidaya, terutama pertumbuhan. Selain karakteristik budidayanya, karakteristik morfologis ikan lele Mutiara juga perlu dieksplorasi. Salah satu aspek morfologi yang perlu dieksplorasi tersebut adalah abnormalitas morfologis benihnya. Penelitian ini bertujuan untuk mengetahui abnormalitas morfologis benih ikan lele Mutiara dibandingkan dengan benih strain-strain ikan lele Afrika lain yang digunakan dalam kegiatan budidaya di Indonesia, yakni ikan lele Sangkuriang, Dumbo, Sukhoi, Burma, Paiton, Phyton dan Masamo. Karakteristik yang diamati adalah abnormalitas bentuk morfologis (deformitas) dan fluktuasi asimetri sirip dada dan sirip perut. Hasil penelitian ini menunjukkan bahwa tingkat deformitas $(4,00 \%)$ dan fluktuasi asimetri (sirip dada 0,14 dan sirip perut 0,02) benih ikan lele Mutiara lebih rendah daripada benih-benih ikan lele Sangkuriang, Dumbo, Sukhoi, Burma, Paiton, Phyton dan Masamo (deformitas berkisar 6,00-42,00\%, fluktuasi asimetri sirip dada berkisar 0,30-0,68 dan sirip perut berkisar 0,12-0,62). Hasil tersebut menunjukkan bahwa bentuk morfologis benih ikan lele Mutiara lebih normal daripada benih-benih ikan lele Sangkuriang, Dumbo, Sukhoi, Burma, Paiton, Phyton dan Masamo. Hal tersebut mengindikasikan bahwa mutu dan keragaman genetis ikan lele Mutiara lebih tinggi daripada strain-strain ikan lele Afrika lain yang digunakan dalam kegiatan budidaya di Indonesia tersebut.
\end{abstract}

KATA KUNCI: deformitas, fluktuasi asimetri, ikan lele Mutiara (Clarias gariepinus)

ABSTRACT: $\quad$ Morphological abnormality of the seeds of Mutiara strain of the African catfish (Clarias gariepinus). By: Bambang Iswanto and Rommy Suprapto

Mutiara is a new genetically improved African catfish (Clarias gariepinus) strain with several superior culture performances, mainly the growth. Besides its culture performances, morphological characteristics of Mutiara strain were also important things should be investigated. One of the such important characteristics was morphological abnormality of the seeds. The present study aimed to investigated the occurrence of morphological abnormalities in the seeds of Mutiara strain compared to those of other African catfish strains cultured in Indonesia, i.e. Sangkuriang, Dumbo, Sukhoi, Burma, Paiton, Phyton, and Masamo strains. The characters investigated in the present study included abnormalities of the body form (deformities) and fluctuating asymmetries of the pectoral and pelvic fins. Results of the present study revealed that deformity $(4.00 \%)$ and fluctuating asymmetry (pectoral fins was 0.14 and pelvic fins was 0.02) of the seeds of Mutiara strain were much lower than those of Sangkuriang, Dumbo, Sukhoi, Burma, Paiton, Phyton and Masamo strains (deformity ranged 6.00\%-42.00\%, fluctuating asymmetry of the pectoral fins ranged 0.30-0.68 and the pelvic fins ranged 0.12-0.62). Those results suggested that the seeds of Mutiara strain was morphologically more normal than the seeds of Sangkuriang, Dumbo, Sukhoi, Burma, Paiton, Phyton and Masamo strains. Thus, indicated that genetic quality and genetic variation of the Mutiara strain were higher than those of other African catfish strains cultured in Indonesia.

KEYWORDS: $\quad$ deformity, fluctuating asymmetry, Mutiara strain of the African catfish (Clarias gariepinus)

\section{PENDAHULUAN}

Ikan lele Clarias gariepinus Burchell 1822 merupakan spesies ikan lele yang berasal dari Afrika dan telah diintroduksi secara luas hampir ke seluruh dunia sebagai ikan budidaya. Ikan lele Afrika tersebut telah beberapa kali diintroduksi ke Indonesia, diawali dengan ikan lele Dumbo pada tahun 1985, diikuti dengan ikan lele Paiton atau CP pada tahun 1998, kemudian ikan lele Mesir pada tahun 2007, ikan lele Masamo pada tahun 2010 serta ikan lele Kenya dan Belanda pada tahun 2011 (BPPI, 2015). Selain strain-strain hasil introduksi tersebut, di Indonesia juga telah dikembangkan strain- 
strain ikan lele Afrika hasil pemuliaan, antara lain ikan lele Sangkuriang, ikan lele Phyton, ikan lele Mandalika, ikan lele Sangkuriang 2, ikan lele Sukhoi dan yang terbaru adalah ikan lele Mutiara (BPPI, 2015).

Ikan lele Mutiara merupakan strain unggul baru ikan lele Afrika hasil pemuliaan Balai Penelitian Pemuliaan Ikan (BPPI) Sukamandi yang telah ditetapkan rilisnya berdasarkan Surat Keputusan Menteri Kelautan dan Perikanan Nomor 77 KEPMEN-KP/2015. Ikan lele Mutiara dibentuk melalui seleksi individu pada karakter laju pertumbuhan selama tiga generasi, sehingga memiliki keunggulan utama pertumbuhan yang cepat. Sebagai strain unggul yang dibentuk melalui proses seleksi individu, selain unggul pada aspek pertumbuhan, ikan lele Mutiara diharapkan juga memiliki keunggulankeunggulan yang lain, salah satunya adalah stabilitas karakteristik morfologisnya. Sebagai strain yang baru dibentuk, ikan lele Mutiara masih memiliki keragaman genetis yang relatif tinggi dengan tingkat inbreeding yang relatif rendah serta tidak menunjukkan penurunan keragaman genetis selama proses seleksinya (BPPI, 2014), sehingga diharapkan stabilitas karakteristik morfologisnya juga relatif tinggi.

Stabilitas karakteristik morfologis tersebut salah satunya diindikasikan dengan tingkat abnormalitas bentuk morfologis. Populasi ikan dengan keragaman genetis yang tinggi memiliki stabilitas kerakteristik morfologis yang tinggi pula, sehingga tingkat abnormalitas morfologisnya rendah. Abnormalitas bentuk morfologis tersebut dinyatakan dengan kelainan atau penyimpangan bentuk organorgan tubuh (deformitas) serta tidak seimbangnya (asimetris) karakterisik meristik (jumlah) di antara pasangan organ-organ bilateral. Tingginya tingkat deformitas dan fluktuasi asimetri karakteristik morfologis mengindikasikan rendahnya keragaman genetis populasi ikan tersebut. Hasil-hasil penelitian menunjukkan adanya hubungan antara abnormalitas morfologis dengan keragaman genetis dan karakterkarakter yang terkait dengan daya tahan (fitness), seperti sintasan dan kerentanan terhadap serangan penyakit (Leary et al., 1985; Palmer \& Strobeck, 1986; Palmer, 1994; Klingenberg \& Nijhout, 1999; Palmer \& Strobeck, 2003; Leamy \& Klingenberg, 2005).

Penelitian fluktuasi asimetri pada ikan hasil pemuliaan telah dilakukan pada ikan nila (Oreochromis niloticus) strain GIFT (Genetically Improved Farmed Tilapia), GST (GenoMar Supreme Tilapia) dan FAST (Freshwater Aquaculture Center Selected Tilapia) di Filipina (Muallil et al., 2014). Pada ikan lele, deformitas dan fluktuasi asimetri pernah dilaporkan pada strain ikan lele Dumbo (Nurhidayat, 2000; Nurhidayat et al., 2003), sedangkan nilai fluktuasi asimetri ikan lele Sangkuriang terdapat dalam Surat Keputusan Menteri Kelautan dan Perikanan Nomor KEP.26/ MEN/2004 tentang pelepasannya sebagai strain unggul. Deformitas dan fluktuasi asimetri pada strain-strain ikan lele Afrika yang lain di Indonesia juga merupakan hal yang umum terjadi (pengamatan pribadi), namun belum pernah dipublikasikan. Penelitian ini bertujuan untuk mengetahui deformitas dan fluktuasi asimetri benih ikan lele Mutiara sebagai strain unggul baru ikan lele Afrika C. gariepinus dibandingkan dengan strainstrain lain yang digunakan oleh para pembudidaya ikan lele di Indonesia. Informasi tersebut penting untuk diketahui berkaitan dengan indikasi tingkat keragaman genetis dan mutu genetisnya.

\section{BAHAN DAN METODE}

Kegiatan karakterisasi deformitas dan fluktuasi asimetri benih ikan lele Mutiara dibandingkan dengan strain-strain yang lain dilakukan di Balai Penelitian Pemuliaan Ikan (BPPI) Sukamandi. Dalam penelitian ini tidak seluruh strain yang ada di Indonesia digunakan sebagai pembanding. Hanya benih dari strain-strain yang biasa dibudidayakan oleh para pembudidaya ikan lele saja yang digunakan, yakni ikan lele Sangkuriang, Dumbo, Paiton, Phyton, Masamo, Sukhoi, dan Burma. Strain-strain yang lain, yakni ikan lele Mesir, Kenya dan Belanda tidak digunakan, karena masih dalam tahap penelitian dan belum digunakan dalam kegiatan budidaya.

Benih ikan lele Sangkuriang yang digunakan pada penelitian ini diperoleh dari Balai Pengembangan Budidaya Air Tawar (BPBAT) Cijengkol yang merupakan unit pelaksana teknis Dinas Perikanan dan Kelautan Provinsi Jawa Barat sebagai penghasil utama strain ikan lele Sangkuriang di Jawa Barat. Benih ikan lele Dumbo diperoleh dari pembenih perorangan di Indramayu sebagai daerah sentra pembesaran ikan lele di Jawa Barat. Benih ikan lele Sukhoi diperoleh dari Balai Layanan Usaha Pengembangan Perikanan Budidaya (BLUPPB) Karawang sebagai penghasil utama strain ikan lele Sukhoi. Benih ikan lele Burma diperoleh dari pembenih perorangan di Dukuhturi, Tegal sebagai daerah sentra penghasil dan pengguna strain ikan lele Burma. Sedangkan, benih-benih strain ikan lele Paiton, Phyton, dan Masamo diperoleh dari pemijahan induk-induk koleksi di BPPI Sukamandi. Induk ikan lele Paiton koleksi BPPI Sukamandi yang digunakan untuk menghasilkan benih pada penelitian ini diperoleh dari Model Pembenihan Ikan Lele (MPIL) Mojokerto sebagai unit pelaksana teknis Dinas Kelautan dan Perikanan Provinsi Jawa Timur yang bertugas mengembangkan ikan lele. Selanjutnya, induk ikan lele Phyton koleksi BPPI Sukamandi diperoleh dari kelompok pembudidaya ikan Sinar Kehidupan Abadi di Pandeglang sebagai penghasil strain tersebut. Induk ikan lele Masamo koleksi BPPI Sukamandi diperoleh dari hatchery PT Matahari Sakti di Mojokerto sebagai penghasil strain tersebut.

Karakterisasi deformitas dan fluktuasi asimetri benih ikan lele Mutiara dan benih-benih strain pembandingnya tersebut dilakukan pada akhir tahap pembesaran, ketika sampel-sampel ikan lele tersebut telah berukuran 
relatif besar, dengan bobot berkisar 50-200 g. Sampel yang digunakan dari masing-masing strain sebanyak 50 ekor, diambil secara acak dari populasi. Karakterisasi deformitas dilakukan melalui pengamatan ada-tidaknya penyimpangan bentuk organ-organ tubuh dibandingkan dengan bentuk individu normalnya, antara lain bentuk badan, bentuk kepala, bentuk sirip punggung, bentuk sirip anal dan bentuk sirip ekor serta lengkap-tidaknya keberadaan sirip dada dan sirip perut. Individuindividu ikan sampel dinyatakan mengalami deformitas jika memiliki satu atau lebih penyimpangan bentuk morfologis (abnormalitas) tersebut. Karakterisasi fluktuasi asimetri dilakukan melalui penghitungan jumlah jari-jari pada pasangan sirip dada dan sirip perut. Individu ikan sampel dinyatakan bersifat asimetris jika jumlah jari-jari sirip dada dan/atau sirip perutnya pada sisi sebelah kanan tidak sama dengan sebelah kirinya. Banyaknya individu ikan sampel yang bersifat asimetris tersebut digunakan untuk menghitung besarnya fluktuasi asimetri, sebagaimana dilakukan pada penelitian karakterisasi fluktuasi asimetri populasipopulasi ikan lele Dumbo (Nurhidayat, 2000; Nurhidayat et al., 2003). Data karakteristik deformitas dan fluktuasi asimetri yang diperoleh dianalisis secara deskriptif.

\section{HASIL DAN BAHASAN}

Hasil karakterisasi bentuk morfologis yang dilakukan pada penelitian ini terhadap sampel-sampel ikan lele Mutiara, Sangkuriang, Dumbo, Sukhoi, Burma, Paiton, Phyton, dan Masamo hasil pembesaran menunjukkan bahwa terdapat beberapa jenis penyimpangan (abnormalitas) bentuk morfologis (deformitas). Deformitas tersebut antara lain berupa tidak adanya salah satu (Gambar 1A) atau kedua (Gambar 1B) sirip dada dan/atau sirip perut (Gambar 2A dan 2B), sirip dada (Gambar 3A) dan/atau sirip perut (Gambar 3B) yang bengkok atau mengecil (rudimenter), sirip punggung yang terputus (terpisah) di bagian tengahnya (Gambar 4A) atau bercabang (Gambar 4B), sirip ekor yang mengecil (Gambar 5A), sirip anal yang terpisah di bagian tengahnya (Gambar 5B), tulang tempurung kepala (dahi) yang sangat menonjol (Gambar 6A) dan bentuk badan yang membengkok (Gambar 6B).

Deformitas yang umum terjadi pada benih ikan lele Mutiara, Sangkuriang, Dumbo, Sukhoi, Burma, Paiton, Phyton, dan Masamo adalah tidak adanya (tidak tumbuhnya) salah satu dan/atau kedua sirip dada dan/ atau sirip perut, sedangkan deformitas pada organ-organ
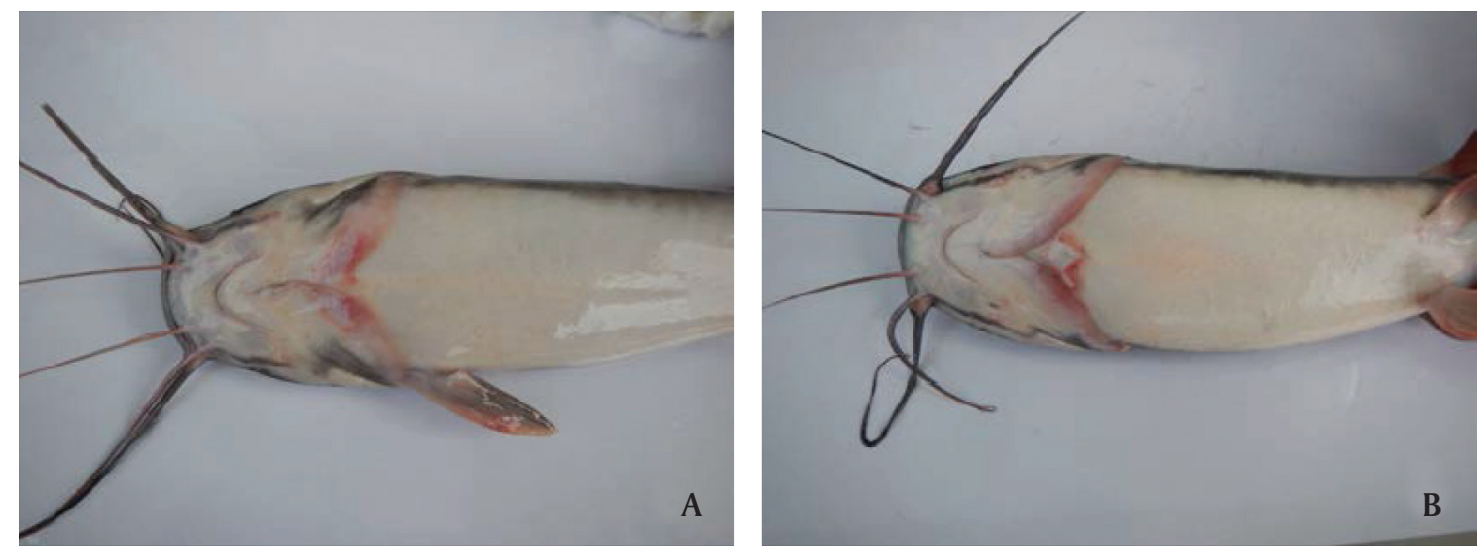

Gambar 1. Deformitas pada salah satu (A) dan kedua (B) sirip dada ikan lele Clarias gariepinus

Figure 1. Deformities on the one side (A) and both sides (B) of the pectoral fins of African catfish (Clarias gariepinus)
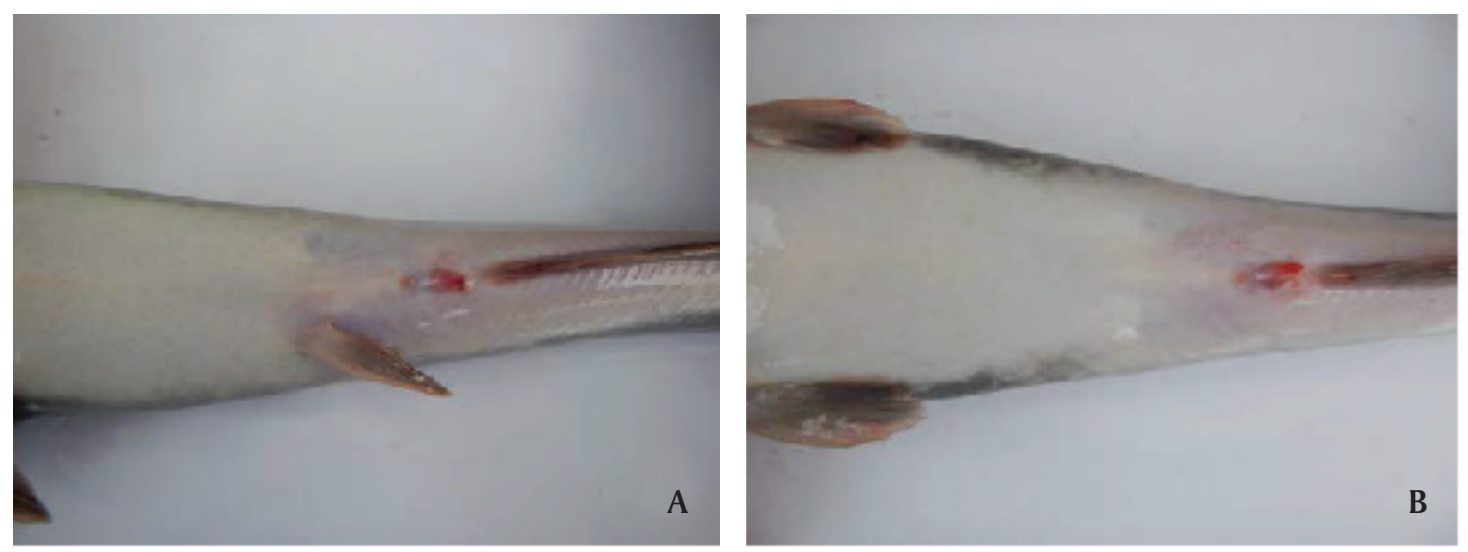

Gambar 2. Deformitas pada salah satu (A) dan kedua (B) sirip perut ikan lele Clarias gariepinus

Figure 2. Deformities on the one side (A) and both sides (B) of the pelvic fins of African catfish (Clarias gariepinus) 

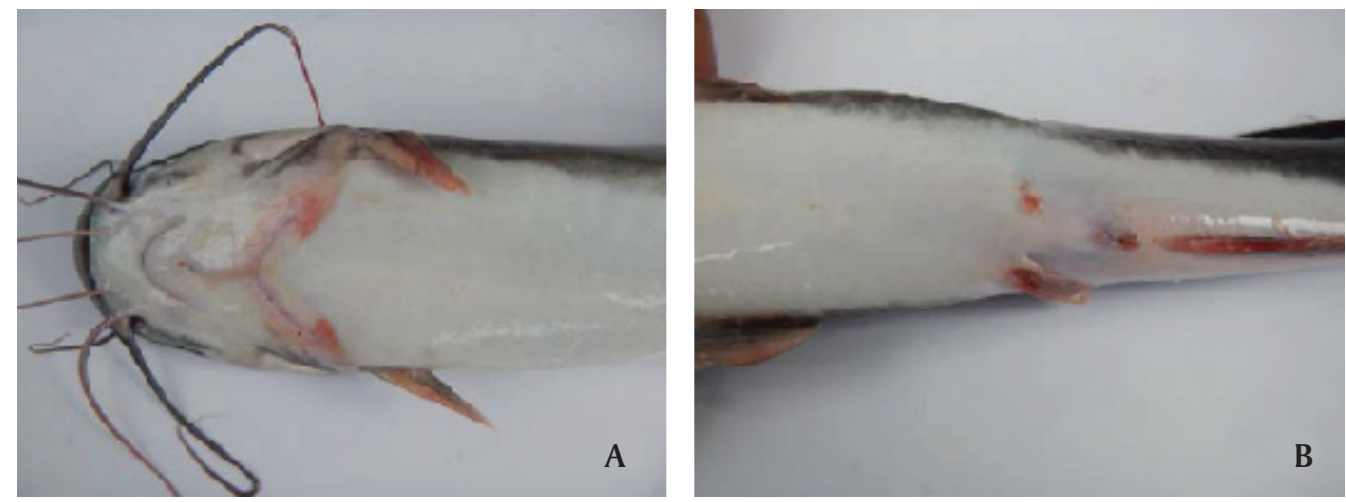

Gambar 3. Deformitas sirip dada (A) dan sirip perut (B) yang bengkok dan mengecil pada ikan lele Clarias gariepinus

Figure 3. Deformities on the pectoral (A) and pelvic (B) fins of the African catfish (Clarias gariepinus) in the form of bent and rudimentary fins
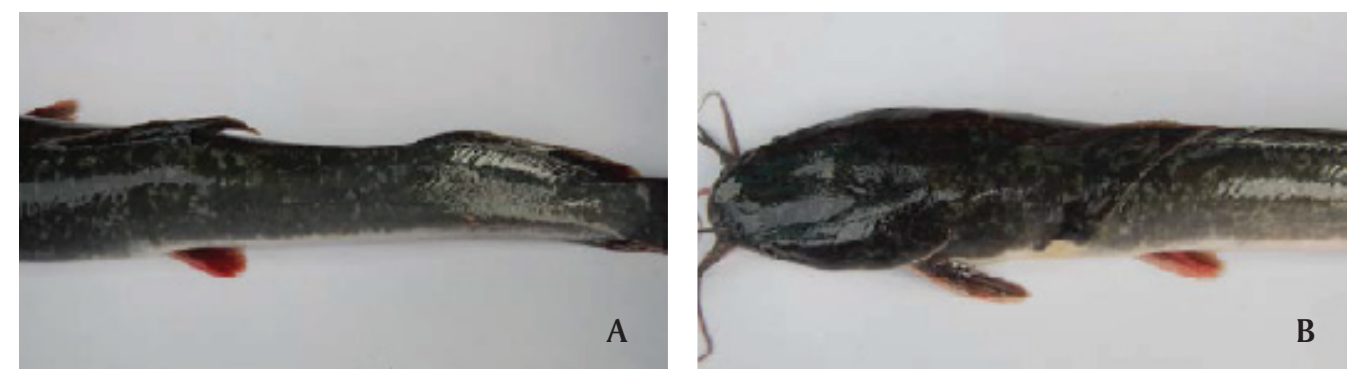

Gambar 4. Deformitas sirip punggung yang terpisah pada bagian tengahnya (A) dan bercabang (B) pada ikan lele Clarias gariepinus

Figure 4. Deformities on the dorsal fin of the African catfish (Clarias gariepinus) in the form of discrete (A) and branched (B) dorsal fins
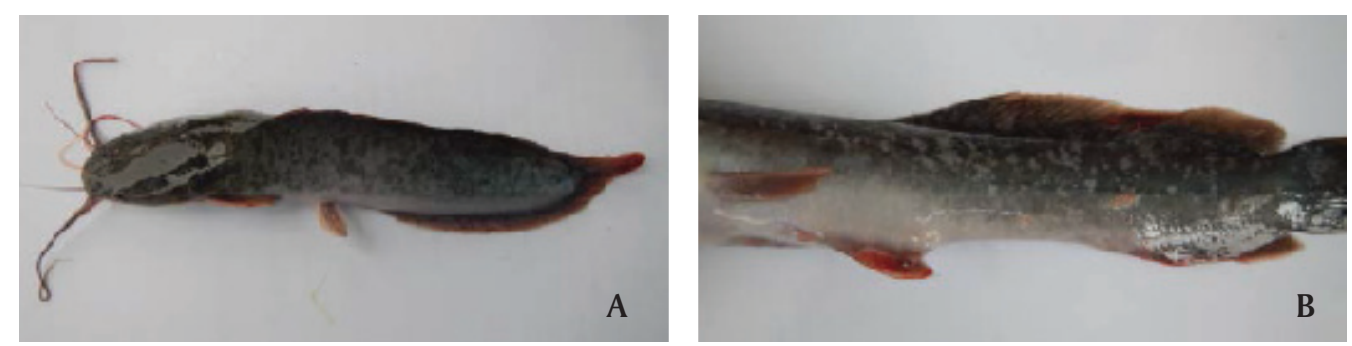

Gambar 5. Deformitas sirip ekor yang mengecil (A) dan siri ekor yang terpisah di bagian tengahnya (B) pada ikan lele Clarias gariepinus

Figure 5. Deformities on the African catfish (Clarias gariepinus) in the form of rudimentary caudal fin (A) and discrete anal fin (B)
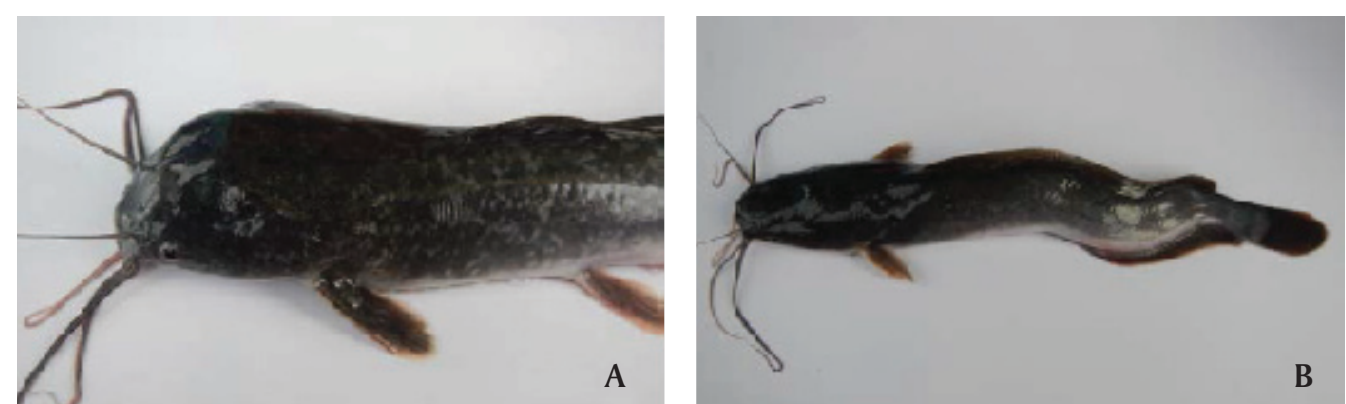

Gambar 6. Deformitas tulang tempurung kepala yang menonjol (A) dan bentuk badan yang membengkok (B) pada ikan lele Clarias gariepinus

Figure 6. Deformities on the African catfish (Clarias gariepinus) in the form of protruding skull (A) and scoliosis (B). 
yang lain relatif kecil. Hasil karakterisasi morfologis pada penelitian ini menunjukkan bahwa deformitas benih ikan lele Mutiara menunjukkan nilai yang jauh lebih rendah daripada benih strain-strain yang lain (Tabel 1). Hasil pengamatan yang dilakukan terhadap 50 ekor sampel ikan lele Mutiara menunjukkan bahwa hanya terdapat dua ekor atau sebesar 4\% individu yang mengalami deformitas. Hasil penelitian ini juga menunjukkan bahwa benih ikan lele Mutiara menunjukkan nilai fluktuasi asimetri yang paling rendah di antara benih strainstrain ikan lele Afrika yang lain, baik untuk fluktuasi asimetri pada sirip dada maupun sirip perut (Tabel 1). Dari sebanyak 50 ekor sampel ikan lele Mutiara hanya tujuh ekor (14\%) individu yang jumlah jari-jari sirip dada sebelah kanan dan kirinya tidak sama (asimetris), sedangkan pada jumlah jari-jari sirip perutnya hanya ada satu ekor (2\%) individu yang jumlahnya berbeda.

Lebih rendahnya tingkat deformitas dan fluktuasi asimetri benih ikan lele Mutiara tersebut menunjukkan bahwa ikan lele Mutiara secara morfologis memiliki bentuk yang lebih normal dan tidak banyak mengalami kecacatan dibandingkan dengan strain-strain ikan lele Afrika lain yang digunakan dalam kegiatan budidaya di Indonesia. Hal tersebut mengindikasikan bahwa mutu genetis ikan lele Mutiara lebih tinggi daripada strain-strain ikan lele Afrika yang lain tersebut. Meskipun deformitas dan fluktuasi asimetri tersebut pada tingkat pembudidaya ikan lele tidak dianggap sebagai suatu permasalahan yang serius, tetapi tingkat deformitas dan fluktuasi asimetri tersebut mencerminkan mutu dari benih-benih ikan lele yang digunakan dalam kegiatan budidaya. Semakin tinggi tingkat deformitas dan fluktuasi asimetrinya, semakin rendah mutu genetis benih tersebut (Sudarto, 2014, komunikasi pribadi). Hasil-hasil penelitian secara umum menunjukkan bahwa semakin tinggi tingkat deformitas dan fluktuasi asimetri, semakin rendah daya tahannya (fitness), sehingga semakin rendah tingkat sintasannya serta semakin rentan terhadap serangan penyakit (Leary et al., 1985; Klingenberg \& Nijhout, 1999; Leamy \& Klingenberg, 2005).

Berdasarkan karakterisasi pada penelitian ini, tingkat deformitas dan fluktuasi asimetri benih strainstrain ikan lele Afrika yang selama ini digunakan dalam kegiatan budidaya di Indonesia menunjukkan nilai yang relatif tinggi. Relatif tingginya tingkat deformitas dan fluktuasi asimetri pada ikan lele Sangkuriang merupakan hal yang wajar, karena ikan lele Sangkuriang merupakan strain yang telah sejak lama dibentuk (Ade Sunarma, 2004, komunikasi pribadi), sehingga setelah lebih dari 10 tahun tentunya telah mengalami penurunan mutu genetis. Terlebih lagi, proses pembentukannya hanya dilakukan melalui proses silang balik (backcross) di antara individu-individu ikan lele Dumbo tertua yang tersisa, sehingga sangat mungkin jumlah induk pembentuknya tersebut tidak banyak yang pada akhirnya mempercepat terjadinya peningkatan inbreeding.

Meskipun sebagai strain-strain hasil rekayasa terbaru, benih-benih ikan lele Burma dan Sukhoi ternyata juga telah menunjukkan tingkat deformitas dan fluktuasi asimetri yang tinggi. Ikan lele Burma (Amir Sobirin, 2014, komunikasi pribadi) dan ikan lele Sukhoi (Dahlan, 2014, komunikasi pribadi) merupakan strain-strain ikan lele Afrika yang dibentuk sekitar tahun 2013 melalui proses persilangan dengan menggunakan ikan lele Masamo yang memiliki keunggulan performa pertumbuhan sebagai salah satu induknya. Meskipun baru diintroduksi dari Thailand pada tahun 2010 (Fauzul Mubin, 2011, komunikasi pribadi), hasil pemijahan induk ikan lele Masamo koleksi BPPI Sukamandi menunjukkan tingkat deformitas dan fluktuasi asimetri yang tinggi.

Tabel 1. Tingkat deformitas dan fluktuasi asimetri benih ikan lele Mutiara dan benih strain-strain ikan lele Afrika (Clarias gariepinus) lain yang dibudidayakan di Indonesia

Table 1. Deformity and fluctuating asymmetry of the seeds of Mutiara strain and other African catfish (Clarias gariepinus) strains cultured in Indonesia

\begin{tabular}{|c|c|c|c|}
\hline \multirow{2}{*}{$\begin{array}{l}\text { Strain } \\
\text { Strains }\end{array}$} & \multirow{2}{*}{$\begin{array}{l}\text { Deformitas (\%) } \\
\text { Deformity (\%) }\end{array}$} & \multicolumn{2}{|c|}{$\begin{array}{l}\text { Fluktuasi asimetri } \\
\text { Fluctuating asymmetry }\end{array}$} \\
\hline & & $\begin{array}{l}\text { Sirip dada } \\
\text { Pectoral Fins }\end{array}$ & $\begin{array}{l}\text { Sirip perut } \\
\text { Pelvic Fins }\end{array}$ \\
\hline Mutiara & 4 & 0,14 & 0,02 \\
\hline Dumbo & 6 & 0,32 & 0,12 \\
\hline Sangkuriang & 8 & 0,38 & 0,18 \\
\hline Burma & 18 & 0,60 & 0,30 \\
\hline Sukhoi & 30 & 0,60 & 0,54 \\
\hline Paiton & 8 & 0,30 & 0,12 \\
\hline Phyton & 12 & 0,42 & 0,14 \\
\hline Masamo & 42 & 0,68 & 0,62 \\
\hline
\end{tabular}


Tingginya tingkat deformitas dan fluktuasi asimetri pada ikan lele Masamo tersebut tampaknya menyebabkan tetap relatif tingginya tingkat deformitas dan fluktuasi asimetri pada strain-strain ikan lele hasil persilangannya. Secara umum, hasil-hasil penelitian menunjukkan bahwa instabilitas perkembangan morfologi terutama dalam bentuk fluktuasi asimetri bersifat genetis (diwariskan), dengan kecenderungan pewarisannya bersifat non-aditif (Leamy \& Klingenberg, 2005).

Hasil karakterisasi morfologis pada penelitian ini juga menunjukkan bahwa benih-benih ikan lele Paiton dan Phyton memiliki tingkat deformitas yang relatif tinggi. Ikan lele Paiton atau ikan lele CP merupakan strain ikan lele Afrika yang diintroduksi pada tahun 1998 dari Thailand dengan keunggulan utama berupa performa pertumbuhan (Nyoman Oka Arsana, 2014, komunikasi pribadi), sebagaimana halnya ikan lele Masamo. Tingginya tingkat deformitas dan fluktuasi asimetri pada strain-strain yang diintroduksi dari Thailand dengan keunggulan utama berupa performa pertumbuhan tersebut mengindikasikan bahwa strainstrain ikan lele Afrika tersebut tampaknya di Thailand telah mengalami tekanan secara genetis melalui proses pemilihan (seleksi) secara terbatas terhadap individu-individu dengan performa pertumbuhan yang tinggi untuk digunakan dalam kegiatan-kegiatan budidaya. Dengan demikian, wajar jika keragaman genetisnya telah mengalami penurunan, sehingga stabilitas perkembangan karakteristik morfologisnya juga rendah. Tingkat deformitas dan fluktuasi asimetri yang relatif tinggi pada ikan lele Paiton tersebut juga diwariskan pada ikan lele Phyton sebagai hasil persilangannya dengan ikan lele Dumbo.

Berdasarkan hasil karakterisasi morfologis pada penelitian ini, benih ikan lele Dumbo sebagai strain yang tidak jelas identitasnya memiliki tingkat deformitas dan fluktuasi asimetri yang relatif rendah. Nama Dumbo saat ini merupakan nama umum yang digunakan untuk menyebut strain-strain ikan lele Afrika yang tidak jelas identitasnya, karena tidak diketahui secara pasti silsilah pembentukannya. Dengan kata lain, istilah Dumbo merupakan nama umum yang saat ini digunakan oleh para pembudidaya untuk menyebut strain-strain ikan lele Afrika selain strain-strain yang memiliki identitas secara jelas. Oleh karena dibentuk dari proses pemijahan dari induk-induk yang tidak jelas identitasnya, maka tingkat deformitas dan fluktuasi asimetri benih ikan lele Dumbo yang dihasilkan juga sangat tergantung dari tingkat deformitas dan fluktuasi asimetri induk-induknya. Benih ikan lele Dumbo yang digunakan pada penelitian ini diperoleh dari pembenih lokal Indramayu. Relatif rendahnya tingkat deformitas dan fluktuasi asimetri benih ikan lele Dumbo lokal Indramayu tersebut tampaknya merupakan akibat dari relatif rendahnya tingkat deformitas dan fluktuasi asimetri induk-induk pembentuknya. Indramayu merupakan daerah sentra pembesaran ikan lele di
Jawa Barat yang membutuhkan benih dalam jumlah yang besar, sehingga untuk memenuhi kebutuhan benih tersebut didatangkan benih-benih dari berbagai daerah sentra pembenihan ikan lele di Indonesia. Dengan demikian, benih-benih yang digunakan dalam pembesaran di Indramayu berasal dari berbagai daerah dan berbagai strain. Selanjutnya, para pembenih lokal Indramayu menggunakan sebagian ikan-ikan lele hasil pembesaran yang memiliki performa pertumbuhan yang tinggi tersebut sebagai calon induk. Oleh karena itu, wajar jika benih-benih ikan lele Dumbo yang berasal dari Indramayu yang digunakan dalam penelitian ini masih memiliki tingkat deformitas dan fluktuasi asimetri yang relatif rendah, karena calon-calon induknya berasal dari ikan-ikan lele hasil pembesaran yang terpilih dan sangat mungkin juga berbeda strain.

Ikan-ikan lele Dumbo yang berasal dari daerah Tulungagung, Sleman dan Bogor dilaporkan memiliki nilai deformitas berkisar $0,00 \%-1,33 \%$ pada sirip dada dan berkisar 0,44\%-27,56\% pada sirip perut (Nurhidayat, 2000; Nurhidayat et al., 2003). Nilai deformitas ikan-ikan lele Dumbo tersebut relatif lebih rendah daripada nilai deformitas sampel benih strain-strain ikan lele Afrika yang digunakan pada penelitian ini. Namun demikian, sebenarnya hal tersebut dikarenakan perbedaan metode identifikasi yang digunakan. Penentuan tingkat deformitas sampel-sampel ikan lele Dumbo yang berasal dari daerah Tulungagung, Sleman dan Bogor tersebut hanya berdasarkan pada tidak adanya pasangan sirip dada dan sirip perut, yakni individu ikan lele Dumbo dinyatakan mengalami deformitas jika sepasang siripnya (baik sirip dada maupun sirip perut) tidak ada, sedangkan individu yang hanya memiliki salah satu sirip (pada sisi kiri ataupun kanan) dikategorikan tidak mengalami deformitas. Sebaliknya, pada penelitian ini individu yang memiliki kelainan, baik berupa tidak adanya salah satu dan/atau sepasang sirip dada dan/atau sirip perut maupun kelainan pada bagian sirip punggung, sirip anal, sirip ekor, bagian kepala dan bagian tubuh lainnya dikategorikan mengalami deformitas. Dengan demikian, wajar jika nilai deformitas yang diperoleh pada penelitian ini relatif lebih tinggi daripada ikan-ikan lele Dumbo yang berasal dari Tulungagung, Sleman, dan Bogor tersebut, karena kriteria yang digunakan untuk menentukan kategori deformitas pada penelitian ini lebih banyak.

\section{KESIMPULAN}

Tingkat deformitas $(4,00 \%)$ dan fluktuasi asimetri (sirip dada 0,14 dan sirip perut 0,02 ) benih ikan lele Mutiara lebih rendah daripada benih strain-strain ikan lele Afrika lain (Dumbo/lokal,Sangkuriang, Sukhoi, Burma, Paiton, Phyton, dan Masamo) yang dibudidayakan di Indonesia (deformitas berkisar 6,00\%42,00\%, fluktuasi asimetri sirip dada berkisar 0,30-0,68 dan sirip perut berkisar 0,12-0,62), menunjukkan bahwa bentuk morfologis benih ikan lele Mutiara lebih normal daripada benih strain-strain yang lain tersebut. 


\section{UCAPAN TERIMA KASIH}

Penulis menyampaikan terima kasih yang sebesarbesarnya kepada para Teknisi Litkayasa peneliti komoditas penelitian pemuliaan ikan lele BPPI Sukamandi atas bantuan teknisnya selama pelaksanaan kegiatan ini. Terima kasih yang sebesar-besarnya juga disampaikan kepada Dr. Sudarto, Amir Sobirin, Dahlan, Fauzul Mubin, Nyoman Oka Arsana, serta para pembudidaya mitra atas bantuan informasi yang diberikan.

\section{DAFTAR ACUAN}

BPPI. (2014). Naskah akademis usulan pelepasan varietas ikan lele tumbuh cepat hasil seleksi individu. Balai Penelitian Pemuliaan Ikan. Sukamandi, $81 \mathrm{hlm}$.

BPPI. (2015). Petunjuk teknis budidaya ikan lele mutiara. Balai Penelitian Pemuliaan Ikan. Sukamandi, $51 \mathrm{hlm}$.

Klingenberg, C.P., \& Nijhout, H.F. (1999). Genetics of fluctuating asymmetry: a developmental model developmental instability. Evolution, 53(2), 358375 .

Leamy, L.L., \& Klingenberg, C.P. (2005). The genetics and evolution of fluctuating asymmetry. Annual Review of Ecology, Evolution and Systematics, 36, 1-21.

Leary, R.F., Allendorf, W., \& Knudson, K.L. (1985). Developmental instability as an indicator of reduced genetic variation in hatchery trout. Transactions of the American Fisheries Society, 114, 230-235.
Muallil, R.N., Basiao, Z.U., Abella, T.A., \& Garcia, L.M.B. (2014). Fluctuating asymmetry in genetically improved Nile tilapia, Oreochromis niloticus (Linnaeus), strains in the Philippines. Philippine Science Letters, 7(2), 420-427 (Short Communication).

Nurhidayat, M.A. (2000). Fluktuasi asimetri dan abnormalitas pada ikan lele dumbo (Clarias sp.) yang berasal dari tiga daerah sentra budidaya di Pulau Jawa. Tesis. Institut Pertanian Bogor. Bogor.

Nurhidayat, M.A., Carman, O., Harris, E., \& Sumantadinata, K. (2003). Fluktuasi asimetri dan abnormalitas pada ikan lele dumbo (Clarias sp.) yang dibudidayakan di kolam.J. Pen. Perik. Indonesia, 9(1), 55-60.

Palmer, A.R. (1994). Fluctuating asymmetry analyses: a primer. In Markow, T.A. (Ed.). Developmental Instability: Its Origin and Evolutionary Implications. Kluwer Academic Publishers. Dordrecht. Netherlands, p. 335-365.

Palmer, A.R., \& Strobeck, C. (1986). Fluctuating asymmetry: measurement, analysis, pattern. Annual Review of Ecology, Evolution and Systematics, 17, 391-421.

Palmer, A.R., \& Strobeck, C. (2003). Fluctuating asymmetry analysis revisited. In Polak, M. (Ed.). Developmental Instability (DI): Causes and Consequences. Oxford University Press. Oxford, p. 279-319. 
